\title{
The Effect of Acupressure on Decreasing Nausea and Vomiting in Pregnant Women in Midwives Independent Practice Sidoarjo
}

\author{
Nanik Handayani*, Yasi Anggasari \\ Nahdlatul Ulama University Surabaya, Indonesia \\ *nanik_handayani@unusa.ac.id
}

\begin{abstract}
Nausea and vomiting are physiological things, they will turn into pathology if not treated properly. The study aimed to analyze the effect of acupressure on reducing nausea and vomiting in pregnant women. The method of this study used Quasy-Experiment. The independent variable was acupressure and the dependent variable was nausea and vomiting. The population of all primigravida pregnant women who experience nausea and vomiting are 40 people. The instrument used acupressure SOP and Score Pregnancy Unique Quantification of Emesis and or Nausea Scoring System (PUQE). The statistical test used the Wilcoxon and Mann Whitney test. The results of the study in the treatment group after being given an acupressure are 9 people have decreased degree of nausea and vomiting. The results of the test using the Wilcoxon-test showed significance value of $\mathrm{p}=$ 0.00 (p-value <0.05) so that H0 was rejected, meaning that acupressure affected reducing nausea and vomiting. Meanwhile, in the control group 10 people had the same post-test and pre-test scores. The results of the Wilcoxon-test significance value $\mathrm{p}=0.679$ ( $\mathrm{p}$-value> 0.05) so that $\mathrm{H} 0$ is accepted, meaning that there is no effect of acupressure on reducing nausea and vomiting. This study concludes that acupressure is effective in reducing nausea and vomiting in primigravida pregnant women.
\end{abstract}

Keywords : Acupressure, Pregnant Women, Nausea, Vomiting

Received August 5, 2020; Revised August 30, 2020; Accepted October 20, 2020

(7) (D) STRADA Jurnal Ilmiah Kesehatan, its website, and the articles published there in are licensed under a Creative Commons Attribution-ShareAlike 


\section{STRADA Jurnal Ilmiah Kesehatan}

DOI: $10.30994 /$ sjik.v9i2.436

ISSN: 2252-3847 (print); 2614-350X (online)

Vol.9 No.2 November 2020 Page.1134-1140

\section{BACKGROUND}

Pregnancy is the growth and development of the intrauterine from conception to the onset of labor. Nausea and vomiting during pregnancy are usually caused by changes in the pregnancy system. There can be various complications of pregnancy, including nausea and vomiting which is often experienced in pregnant women, this condition is one of the earliest symptoms of pregnancy, when gestational nausea or vomiting is most common. At 12-16 weeks of gestation, at which time hCG reaches its highest level (Tiran, 2009). Nausea and vomiting occur in $60-80 \%$ of primigravidas and $40-60 \%$ in multigravidas. Physiologically, nausea occurs due to increased levels of estrogen in the blood so that it affects the digestive system (Prawirohardjo, 2009).

Treatment to reduce nausea and vomiting in pregnant women can be done by means of pharmacological and non-pharmacological therapies. Pharmacological therapy is carried out by administering antihistamines, antiemitics, and corticosteroids. Nonpharmacological therapy is carried out by regulating diet, emotional support, and using acupressure (Runiari, 2010). Nausea and vomiting can be reduced by giving acupressure using the Neiguan point (pericardium point 6) which is located between the tendons, namely the flexor carpi radialis and the palmar longus muscle, approximately 3 fingers above the fold of the hand. The stimulating effect of this point is believed to be able to increase the release of beta-endorphins in the pituitary and ACTH (Adrenocorticotropic Hormone) along the Chemoreceptor Trigger Zone (CTZ) inhibiting the vomiting center (BKTM, 2013). In this case, the stimulation at the point of the pericardium 6 is directly related to the median nerve because the point of the pericardium 6 is directly above the nerve (Mercola, 2001).

Acupuncture treatment that uses needles and heating devices can be developed into treatment using massage (using fingers instead of needles), but still based on acupuncture theory (Sukanta, 2008).

\section{METHODS}

This research is Quasy-Experiment with pre-post test control group design approach. The independent variable acupressure and the dependent variable nausea and vomiting. The population of all primigravida pregnant women who experience nausea and vomiting. The sample of 40 people was divided into 20 people who were given treatment and 20 people as controls using purposive sampling. The research was conducted from April to September 2020 at the Midwife Independent Practice Sidoarjo. The acupressure SOP research instruments and Score Pregnancy Unique Quantification of Emesis or Nausea Scoring System (PUQE). The statistical test used the Wilcoxon and Mann Whitney tests. with a significance level of $\alpha=0.05$. If the statistical test results show $\rho<0.05$ then the hypothesis $(\mathrm{H} 0)$ is rejected, which means that acupressure affects reducing nausea and vomiting in pregnant women. This study has passed the Ethics test on March 25, 2020 with certificate number 054 / EC / KEPK / UNUSA / 2020.

\section{RESULTS}

The results of this study are:

\section{Univariate Analysis}

The characteristics of respondents that will be described in the univariate analysis of this study include characteristics of respondents according to age, gestational age, and 


\section{STRADA Jurnal Ilmiah Kesehatan}

DOI: $10.30994 /$ sjik.v9i2.436

ISSN: 2252-3847 (print); 2614-350X (online)

Vol.9 No.2 November 2020 Page.1134-1140

occupation. The frequency distribution of the characteristics of the research respondents is shown in the following table:

Table 1. General characteristics of respondents

\begin{tabular}{|c|c|c|c|c|c|c|}
\hline \multirow{3}{*}{$\begin{array}{l}\text { Respondent } \\
\text { characteristics }\end{array}$} & \multicolumn{4}{|c|}{ Group } & \multicolumn{2}{|c|}{ Total } \\
\hline & \multicolumn{2}{|c|}{$\begin{array}{c}\mathrm{K} 1 \\
\text { (treatment) } \\
(\mathrm{n}=20)\end{array}$} & \multicolumn{2}{|c|}{$\begin{array}{c}\mathrm{K} 2 \\
(\text { control }) \\
(\mathrm{n}=20)\end{array}$} & \multirow[b]{2}{*}{ f } & \multirow[b]{2}{*}{$\%$} \\
\hline & $\mathrm{F}$ & $\%$ & $\mathrm{~F}$ & $\%$ & & \\
\hline \multicolumn{7}{|l|}{ Age range } \\
\hline $15-19$ years old & 0 & 0 & 0 & 0 & 0 & 0 \\
\hline 20 - 35 years old & 19 & 95 & 20 & 100 & 39 & 97,5 \\
\hline $36-45$ years old & 1 & 5 & 0 & 0 & 1 & 2,5 \\
\hline Total & 20 & 100 & 20 & 100 & 40 & 100 \\
\hline \multicolumn{7}{|l|}{ Gestational Age } \\
\hline $0-12$ & & & & & & \\
\hline $13-27$ & 20 & 100 & 14 & 70 & 34 & 85 \\
\hline \multirow{2}{*}{$28-40$} & 0 & 0 & 6 & 30 & 6 & 15 \\
\hline & 0 & 0 & 0 & 0 & 0 & 0 \\
\hline Total & 20 & 100 & 20 & 100 & 40 & 100 \\
\hline \multicolumn{7}{|l|}{ Profession } \\
\hline Housewife & 17 & 85 & 18 & 90 & 35 & 87,5 \\
\hline Private employee & 3 & 15 & 2 & 10 & 5 & 1,25 \\
\hline Entrepreneur & 0 & 0 & 0 & 0 & 0 & 0 \\
\hline Civil servant & 0 & 0 & 0 & 0 & 0 & 0 \\
\hline Total & 20 & 100 & 20 & 100 & 40 & 100 \\
\hline
\end{tabular}

Based on table 1, the frequency distribution according to age shows that almost all (95\%) of the respondents in the treatment group are at the age of 20-35 years, while for the control group respondents all (100\%) are also in the 20-35 years group

\section{Bivariate Analysis}

The bivariate analysis conducted in this study was to determine the effect pf acupressure on reducing nausea and vomiting in pregnant women.

Table 2. The Results of Normality Test Data on the degree of nausea and vomiting before and after acupressure were shown in the treatment and control groups

\begin{tabular}{|c|c|c|c|}
\hline \multicolumn{4}{|l|}{ Shapiro-Wilk } \\
\hline $\begin{array}{l}\text { The degree of nausea } \\
\text { and vomiting }\end{array}$ & Statistic & Df & $\rho^{*}$ \\
\hline Pre-test score & 0,821 & 40 & 0,000 \\
\hline Post-test score & 0,864 & 40 & 0,000 \\
\hline
\end{tabular}

*p $<0,05$ Based on shapiro wilk test 


\section{STRADA Jurnal Ilmiah Kesehatan}

DOI: $10.30994 /$ sjik.v9i2.436

ISSN: 2252-3847 (print); 2614-350X (online)

Vol.9 No.2 November 2020 Page.1134-1140

Based on table 2, the results of the Shapiro-Wilk test shows the value at pre-test and post-test, the significance value of 0.000 ( $p$-value $<0.05)$ means that the nausea and vomiting of pregnant women before getting acupressure and after getting acupressure were not normally distributed, so data analysis used non-parametric test (Wilcoxon and Mann Whitney).

Table 3. The Degree of nausea and vomiting in the treatment group

\begin{tabular}{clccccc}
\hline & $\mathrm{N}$ & Mean Rank & $\begin{array}{c}\text { Sum of } \\
\text { Ranks }\end{array}$ & Z hit & Sig. \\
\hline $\begin{array}{l}\text { Negative } \\
\text { ranks }\end{array}$ & $19^{\mathrm{a}}$ & 10.00 & 190.00 & & \\
Pre-post score & $\begin{array}{l}\text { Positive } \\
\text { Ranks } \\
\text { Ties }\end{array}$ & $0^{\mathrm{b}}$ & 0.00 & 0.00 & $-3,858^{\mathrm{b}}$ & 0,00 \\
& $1^{\mathrm{c}}$ & & & & \\
\cline { 2 - 6 } & & & & & \\
\hline
\end{tabular}

Based on table 3, it shows the negative rank results of 19, meaning that there are 19 people whose post-test scores are lower than the pre-test and positive ranks of 0 , meaning that there are no people whose post-test scores are higher than the pre-test. The value of Ties 1 means that there is 1 person who scores the same post-test and pretest. The results of the test using the Wilcoxon-test, the results of the $\mathrm{Z}$ value were 3.858 and a significance of 0.00 ( $p$-value $<0.05)$ so that $\mathrm{H} 0$ was rejected, meaning that acupressure had an effect on reducing nausea and vomiting in pregnant women.

Table 4. The degree of nausea and vomiting in the control group

\begin{tabular}{clccccc}
\hline & $\mathrm{N}$ & Mean Rank & $\begin{array}{c}\text { Sum of } \\
\text { Ranks }\end{array}$ & Z hit & Sig. \\
\hline \multirow{2}{*}{$\begin{array}{l}\text { Negative } \\
\text { ranks }\end{array}$} & $7^{\mathrm{a}}$ & 4.50 & 31.50 & & \\
test score & $\begin{array}{l}\text { Positive } \\
\text { Ranks }\end{array}$ & $3^{\mathrm{b}}$ & 7.83 & 23.50 & $-414^{\mathrm{b}}$ & 0,679 \\
& Ties & $10^{\mathrm{c}}$ & & & & \\
& Total & 20 & & & & \\
\hline
\end{tabular}

Based on table 4, the negative rank results are 7 , meaning that 7 people have a post-test score lower than the pre-test and a positive rank 3 means that 3 people have a post-test score higher than the pre-test. The Ties value of 10 means that the post test and pre test scores are the same. The results of the test using the Wilcoxon-test, the results of the $\mathrm{Z}$ value were -414 and the significance was 0.679 ( $\mathrm{p}$-value >0.05) so that $\mathrm{H} 0$ was accepted, meaning there was no effect of acupressure on reducing nausea and vomiting in pregnant women 


\section{STRADA Jurnal Ilmiah Kesehatan}

DOI: $10.30994 /$ sjik.v9i2.436

ISSN: 2252-3847 (print); 2614-350X (online)

Vol.9 No.2 November 2020 Page.1134-1140

Table 5. The differences in the degree of nausea and vomiting pre-test at the treatment group and the control group

\begin{tabular}{lccc}
\hline Group & Mean & $\mathrm{n}$ & $P$ value \\
\hline Treatment & 25,10 & 20 & 0.011 \\
Control & 15,90 & 20 & \\
\hline
\end{tabular}

Based on table 5, it obtained a significant result of 0.011 ( $p$-value $<0.05$ ) so that $\mathrm{HO}$ is accepted, meaning that there is no significant difference in the degree of nausea and vomiting in pregnant women during pre-test in the treatment group and the control group

Table 6. The differences in the degree of nausea and vomiting post-test in the treatment group and the control group.

\begin{tabular}{lccc}
\hline Group & Mean & $\mathrm{n}$ & $P$ value \\
\hline Intervention & 23.82 & 20 & 0.061 \\
Control & 17.18 & 20 & \\
\hline
\end{tabular}

Based on table 6 , it is obtained a significant result of 0.61 ( $p$-value $>0.05$ ) so that $\mathrm{H} 0$ is rejected, meaning that there is significant difference in the degree of nausea and vomiting in pregnant women during the post-test in the treatment group and the control group

\section{DISCUSSION}

Based on the results of the study, the frequency distribution according to gestational age showed that all $(100 \%)$ respondents in the treatment group had a gestational age in the first trimester (0-12 weeks), while in the control group most of the respondent $(70 \%)$ were also in the first trimester of pregnancy. Nausea and vomiting are complaint that are often experienced by pregnant women, especially in the first trimester (Lacasse, A. et al 2009). The symptoms usually appear at 7-12 weeks of gestation (Chandra, K. et al, 2002). The characteristics of respondents based on the majority of occupations are not working. The majority of respondents are housewives. In this case mood instability is often experienced by housewives. Emotional responses and assumptions that often arise in women who do not work or often stay at home tend to be negative, for example, anxious to think about changes in body condition (Sofiana et al, 2012). This condition is a supporting factor for nausea and vomiting in pregnant women.

There are several studies that combine acupressure with other therapies, namely with drugs or herbs given orally, such as a study conducted by Mattawan (2007) on 33 pregnant women by providing acupressure bracelet therapy (sea-band) which has a button to provide emphasis. At the neiguan point or point P6 for 7 days and taking tablets identical to vitamin B6 taken every 12 hours for 5 days from the results of the study found that acupressure therapy was no more effective than vitamin B6 in reducing nausea and vomiting in women in the first trimester of pregnancy In this case, with acupressure the nerve cells have activated the drug content in the body. Drugs are given from outside the body affect the working function of the drugs in the body, so that the acupressure function does not work optimally. This results in acupressure not being better at dealing with nausea and vomiting in pregnant women. Acupressure treatment does not need to consume drugs, herbs, and herbs because with acupressure therapy the human body already contains medicinal properties in the body, so it only remains to be activated by the body's nerve 


\section{STRADA Jurnal Ilmiah Kesehatan}

DOI: $10.30994 /$ sjik.v9i2.436

ISSN: 2252-3847 (print); 2614-350X (online)

Vol.9 No.2 November 2020 Page.1134-1140

Vomiting occurs as a result of the stimulation of the vomiting center located in the postrema medulla oblongata at the base of the fourth ventricle. Vomiting can be stimulated through afferent nerve pathways by stimulation of the vagus and sympathetic nerves or by emetic stimulation which causes vomiting with activation of the chemoreceptor trigger zone (Anggi, 2010). The stimulus in CTZ is delivered to the vomiting center which causes the muscles in the gastrointestinal tract and breathing to initiate nausea and vomiting (Tiran, 2009).

Based on table 6 using the Mann-Whitney $U$ test, the results obtained a significance of 0.061 ( $\mathrm{p}$-value> 0.05 ) so that $\mathrm{H} 0$ is rejected, meaning that there is a significant difference in the degree of nausea and vomiting in pregnant women during the post-test in the treatment group and the control group.

According to Albana (2009) in Anggi (2010) Acupressure works quite quickly, usually one to two minutes, for sufferers who experience indigestion. Acupressure is believed to be effective in reducing nausea and vomiting through its effect on increasing beta-endorphins. This substance is one of the natural anti-emetics that can reduce the vomiting stimulus in the CTZ (Chemoreceptor Trigger Zone) and the vomiting center so that it can reduce nausea and vomiting (Syarif, 2009).

\section{CONCLUSIONS}

Pregnant women who are given acupressure have a decreased degree of nausea and vomiting. Acupressure action effectively reduces nausea and vomiting in primigravida pregnant women at PBM Sidoarjo.

\section{REFERENCES}

Anggi, Purnama. (2010). Efektivitas Akupresur Terhadap Penurunan Mual dan Muntah pada Ibu Hamil Trimester Pertama di Kelurahan Jati Karya Kecamatan Binjai Utara Kota Binjai. Medan : Fakultas Keperawatan Universitas Sumatera Utara

Balai kesehatan tradisional masyarakat Makassar. (2013). Efektivitas Akupresur Terhadap Keluhan Mual Muntah pada Ibu Hamil Trimester Pertama di Kota Makassar tahun 2013. Makassar : BKTM

Fengge, A. (2012). Terapi akupresur manfaat dan teknik pengobatan. Yogyakarta: Crop Circle Corp.

Mattawan, J., Vorapong, P. (2007). Acupressure and vitamin B6 to relieve nausea and vomiting in pregnancy. Arch Gynecol Obstetrics journal, 276 (3), 245-249

Mercola. (2001). Acupressure Can Relieve Morning Sikcness. The Journal of Reproductive Medicine.

Murtie, Afin. (2013). Kupas Tuntas Pengobatan Tradisional: Pemahaman, Manfaat, Teknik, \& Praktik. Yogyakarta: Trans Idea

Nirwana, Ade Benih. (2011). Kapita Selekta Kehamilan. Yogyakarta: Nuha Medika

Prawirohardjo. (2009). Buku Asuhan Pelayanan Kesehatan maternal dan Neonatal. Jakarta: Yayasan Bina Pustaka.

Rad, Mogjan Naeimi et al. (2012). A Randomized Clinical Trial of the Efficacy of KID21 Point (Youmen) Acupressure on Nausea and Vomiting of Pregnancy. Iranian Red Crescent Medical Journal (2012) Nov; 14(11): 697-701

Runiari, Nengah. (2010). Asuhan Keperawatan pada Klien dengan Hiperemesis Gravidarum: Penerapan Konsep dan Teori Keperawatan. Jakarta: Salemba Medika. 


\section{STRADA Jurnal Ilmiah Kesehatan}

DOI: $10.30994 /$ sjik.v9i2.436

ISSN: 2252-3847 (print); 2614-350X (online)

Vol.9 No.2 November 2020 Page.1134-1140

Sukanta, Putu Oka. (2008). Pijat Akupresur Untuk Kesehatan. Jakarta: Penebar Plus

Syarif, Hilman. (2009). Pengaruh Terapi Akupresur Terhadap Muak Muntah Akut Akibat

Kemoterapi Pada Pasien Kanker: A Randomized Clinical Trial. Idea Nursing Journal Vol II, No. 2, 137 - 142

Sofiana, LI, Elita, V, dan Utomo, W (2012), 'Hubungan Antara Stress Dengan Konsep Diri Pada Penderita Diabetes Mellitus Tipe 2', Jurnal Ners Indonesia, Vol. 2, No. 2, Maret 2012350 diakses dari www.ncbi.nlm.nih.gov//pmc/articles/pdf

Tiran, Denise. (2009). Mual dan Muntah Kehamilan. Jakarta: EGC 